TROUBLING TRANSPARENCY 



\section{TROUBLING TRANSPARENCY}

\section{THE HISTORY AND FUTURE OF FREEDOM OF INFORMATION}

Edited by David E. Pozen and Michael Schudson 
COLUMBIA UNIVERSITY PRESS

Publishers Since 1893

New York Chichester, West Sussex

cup.columbia.edu

Copyright (C) 2018 Columbia University Press

All rights reserved

Library of Congress Cataloging-in-Publication Data

Names: Pozen, David E., editor. | Schudson, Michael, editor.

Title: Troubling transparency : the history and future of freedom of information / Edited by David Pozen and Michael Schudson.

Description: New York : Columbia University Press, 2018. | Includes index.

Identifiers: LCCN 2017061191 (print) | LCCN 2018000742 (ebook) |

ISBN 9780231545808 (electronic) | ISBN 9780231184984 (cloth : alk. paper) |

ISBN 9780231184991 (pbk.)

Subjects: LCSH: United States. Freedom of Information Act.

Government information--United States. | Public records-Law

and legislation-United States.

Classification: LCC KF5753 (ebook) | LCC KF5753 .T76 2018 (print) |

DDC 342.73/0662--dc23

LC record available at https://lccn.loc.gov/2017061191

Columbia University Press books are printed on permanent and durable acid-free paper.

Printed in the United States of America

Cover design: Milenda Nan Ok Lee

Cover art: Blend Images / (C) Alamy 